IJORER : International Journal of Recent Educational Research Homepage : https://journal.ia-education.com/index.php/ijorer Email : ijorer@ia-education.com
p-ISSN : 2721-852X ; e-ISSN : 2721-7965 IJORER, Vol. 2, No. 2, March 2021: 171-183 (C) 2021 IJORER :

International Journal of Recent Educational Research

\title{
Development of OrSAEv Model Learning Materials Based on Role- Playing of Against Flood Disaster Mitigation Preparedness, Anxiety and Enjoyment of Junior High School
}

\author{
Novia W. Kusumaningrum ${ }^{1 *}$, Madlazim², Tarzan Purnomo ${ }^{3}$ \\ 1,2,3 Science Education Postgraduate Program, Universitas Negeri Surabaya, Surabaya, Indonesia
}

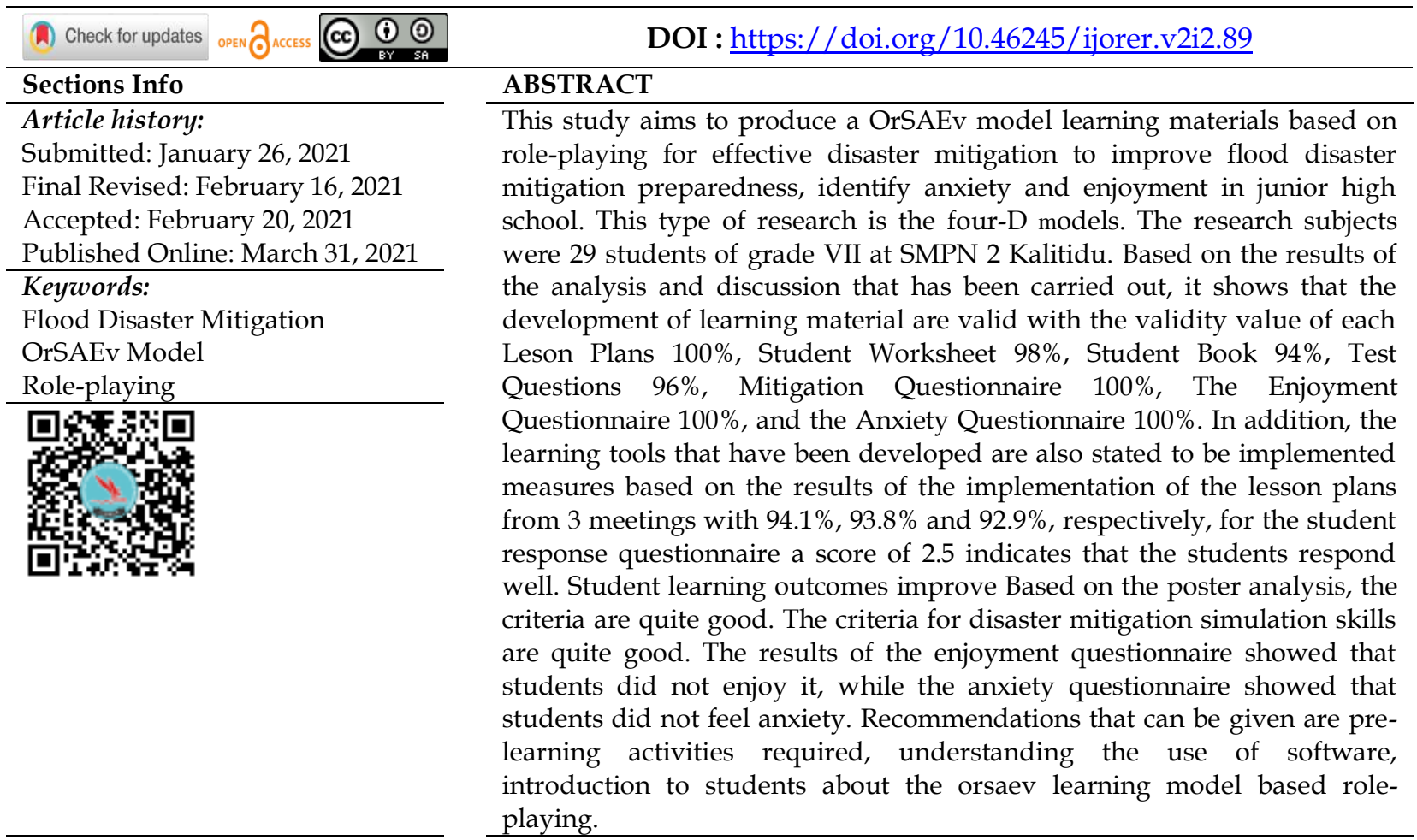

\section{INTRODUCTION}

Learning disaster mitigation preparedness covers various aspects of the realm including, attitudes, knowledge and skills. To improve these three domains, first a description of the experience and knowledge of students is needed. The regional background used as the object of research is one of the supporters of initial knowledge (Siregar, 2020) and student interaction in learning (Suharli, 2015). Bojonegoro, East Java Province, Indonesia is an area with a concave geographic structure, making it prone to flood disasters, one of the villages that is regularly flooded is Ringinrejo Village, Kalitidu District. This can be seen from the map, the area through which the Bengawan Solo river flows is a lowland area (TIM Redaksi, 2013). There are schools that are within the scope of this area, namely public junior high school 2 Kalitidu. The three aspects previously mentioned become a reference for learning about flood disaster mitigation in junior high school students who are basic education communities. Hope in the future, students can successfully take action in the event of a flood, a vigilant attitude towards signs of flooding, and knowledge of mitigation actions that can be done both individually and in groups. In reality, mitigation learning is not relevant to what teachers and schools expect. The learning process seems to rely more on books and innovative models and learning tools are needed specifically to strengthen the 
character of disaster mitigation, especially flood disasters for students worksheets but that is also due to a lack of initiative to develop real learning and to fully involve students in the learning. Therefore, innovative models and learning tools are needed specifically to strengthen the character of disaster mitigation, especially flood disasters for students.

Until now, most research on disaster mitigation preparedness using the OrSAEv learning model (Orientation, Preparedness, Action, Evaluation) focuses on knowledge of earthquakes and tsunami (Elfiana et al., 2019), tsunami disaster mitigation skills (Rahayu et al., 2019), strengthening the character of tsunami disaster mitigation (Isna et al., 2019). For novelty in research, researchers designed and developed learning tools using the OrSAEv learning model model based role-playing. These learning tools are used to improve flood disaster mitigation preparedness. In the realm of skills, students take action, namely simulating flood disaster mitigation using the role-playing method. The research will investigate students feelings of anxiety and enjoyment. The purpose of this study was to produce a OrSAev learning model materials based role-playing for effective disaster mitigation materials to improve flood disaster mitigation preparedness, identify anxiety and enjoyment in junior high school students.

In this research, it discusses the feasibility of the role-playing based OrSAEv learning model based on the assessments of validators, observers and students. Furthermore, the elaboration of the relationship between student anxiety and enjoyment before and during the food disaster mitigation simulation.

The linkage of knowledge of disaster mitigation with children at the elementary school level is described (Sari et al., 2014) to build a culture of security and resilience in the face of disasters. Students are able to act quickly, precisely and accurately when facing disasters (Desfandi, 2014), from the knowledge they have can help people to save themselves and their groups in the future (Marskole et al., 2018). Increasing in-depth and comprehensive knowledge about natural disasters (Atmojo et al., 2018), reducing the risk of material and immaterial community groups (Winarmi \& Purwandi, 2018).

To get disaster mitigation preparedness, it is necessary to determine the level of individual awareness about disaster problems (Dikmenli, 2018). Auxiliary factors for measuring disaster preparedness include students' perceptions, attitudes and experiences (Tkachuck et al., 2016). Disaster preparedness curriculum components in education (Jose \& Dufrene, 2014), in addition to fostering disaster awareness and values in it, mitigation materials can be included through schools (Kastolani \& Mainaki, 2018).

The OrSAEv model is learning to improve students' natural disaster preparedness, which is supported by the use of ICT-related disaster applications in every part of the activity (Madlazim et al., 2019). The syntax of the OrSAEv Model is as follows: 1) Orientation, achievement indicators in the form of students interested in and wanting to contribute to the learning process, 2) Disaster preparedness, with the achievement of student disaster knowledge indicators, 3) Action, the achievement of indicators such as disaster response attitudes and post-evacuation skills. Disaster, 4) Evaluation, desired indicator achievement Evaluation of awareness, attitudes towards flood disasters carried out by teachers and concluded with students. This conscious attitude is in the form of flood disaster evacuation skills in the school environment.

From the syntax, it can be seen that students are required to be more active, while the teacher acts as a facilitator, consultant and mentor. Because students are invited to 
directly play a role regarding actions that should be taken when a disaster occurs and improvements that can be made after a disaster, so that the knowledge students have during learning at school can be applied directly in the context of the real world.

In role playing it is expected that feelings and enjoyment (Wirth et al., 2013), the combination of role playing in learning is proven to be effective in increasing enjoyment and involvement in learning (Walcott \& Corbin-Babb, 2016), because players are always challenged to issue positive feelings such as joy. Fun not only causes motivation, but also cognitive load. However, both of these can have opposite effects, namely high cognitive load leading to low motivation (Brom et al., 2019).

Role-playing is especially suitable for teaching cases of geological hazards (Hales \& Cashman, 2018), floods (Wang et al., 2019), volcanic eruption hazards (Dohaney et al., 2015), earthquake (Indriasari, 2016), adaptation to natural disasters (Paruhita, 2020), as it promises to reduce the damage caused by human activity and human physical activity. Simulations are used to equip students with knowledge of natural disasters in accordance with the actual situation, both in family life, society, and the world of work, simulations can develop students creativity, because through simulations students are given opportunity to play a role according to the simulated topic; simulations can cultivate students courage and confidence, increase knowledge of various situations; simulations can increase student enthusiasm in the learning process (Syuaib, 2013).

Simulation experiences can show students' anxiety levels (Nielsen \& Harden, 2013), Feelings of anxiety in simulations can be reduced by mentoring, role orientation, supportive and friendly environment (Cobbett \& Snelgrove-clarke, 2016). So, that the desired problem formulation of this research is the validity, practicality, and effectiveness of the OrSAEv model learning materials based on role-playing of flood disaster mitigation readiness, anxiety and enjoyment of junior high school students.

\section{RESEARCH METHOD \\ General Background}

This type of research is the development of learning tools with a four-D (define, design, develop, and disseminate) models. The method used is descriptive quantitative. The research subjects were 29 students of grade VII at State Junior High School 2 Kalitidu.

\section{Instrument and Procedures}

The instruments used in data collection included (1) Knowledge and preparedness test sheets for flood disaster mitigation, (2) Questionnaires, referring to the standard manual for disaster preparedness services. The enjoyment questionnaire refers (Fidzgerald et al., n.d) to which measures enjoyment in physical activity with a 4-point Likert scale ranging from 1 ("Strongly disagree") to 4 ("Strongly agree") items (e.g. I feel happy during the "I'm happy" simulation) it indicates a positive answer, thus, a higher score indicates a high enjoyment. An anxiety questionnaire was used in the anxiety questionnaire developed by (Fernandes et al., 2015) to measure the level of anxiety when conducting disaster mitigation simulations with a 4-point linkert scale, ranging from ("strongly disagree") to ("strongly agree"), the items used (e.g. I have signs of nervousness such as sweaty palms, trembling hands, etc. before the simulation "strongly disagree") it indicates a positive answer, thus lower scores indicate lower anxiety levels. 


\section{Data Analysis}

Interpretation of the test for the level of students knowledge about flood disasters, normality test to find out normally distributed samples, homogeneity test to assess variance equality, Paired T-test to determine the pretest and post-test results of disaster knowledge from before and after learning with the OrSAEv Model based on roleplaying, ANCOVA test to determine the increase from the pretest and posttest, besides that. The output of student skills in the form of posters and videos of students in disaster mitigation simulations with the role of each student (role-playing). The skill assessment refers to the rubric that has been made. The level of enjoyment and student anxiety is assessed by dividing the number of scores obtained by the maximum score multiplied by 100 .

\section{RESULTS AND DISCUSSION}

The results of this study are divided into several parts, as follows: (1) Informing the validity, practicality and effectiveness of learning tools based on instrument assessments from validators, observers and students (2) Informing the results of student anxiety when conducting simulations (3) Informing the results of student enjoyment while doing simulation.

\section{Feasibility of learning tools based on instrument assessment from validators, observers and students}

Based on the suggestions and input that have been given by the learning device validator, an analysis can be carried out as shown in Table 1

Table 1. Presentation of the results of the PA value that has been given by the validator.

\begin{tabular}{cc} 
Validated devices & PA Value \\
Lesson Plans & 100 \\
Student worksheet & 98 \\
Student Book & 94 \\
Test Questions & 96 \\
Mitigation Questionnaire & 100 \\
Enjoyment Questionnaire & 100 \\
Anxiety Questionnaire & 100 \\
\hline
\end{tabular}

This section explains the results of the assessment of learning tools by two validators. The Lesson Plans of the role-playing-based OrSAEv model developed was valid, with the validity value shown in the Precentage of Agreement (PA) value, it was known that the compatibility of the observations made by the two observers or validators for the lesson plans were 100\%. The development of the lesson plan refers to the syllabus that has been made previously and has been validated by the two validators. The syllabus and lesson plans have gone through a process of improvement based on suggestions from the validator and then tested. According to Permendikbud (2016) the syllabus was a reference for preparing a learning framework for each subject study material. In this study, a syllabus was developed that is tailored to the needs, namely the science syllabus for junior high school curriculum 2013 on disaster mitigation material. Meanwhile, lesson Plans are developed from the syllabus to direct the learning activities of students in an effort to achieve Basic Competence, lesson plans play a vital role in the learning process in class. Accourding to Farrel in Nesari \& Heidari 
Development of OrSAEv Model Learning Materials Based on Role-Playing of Against Flood Disaster Mitigation Preparedness, Anxiety and Enjoyment of Junior High School

(2014) lesson plan is a part or unit of learning which contains sequence of lessons that correlate to a particular theme or can be determined as a systematic record of a teachers thoughts about deliver of material during lessons. In this activity, lesson plan is used with an online system, considering the impact of the Education sector due to the Covid19 virus so that the government calls for the implementation of distance learning.

The developed student worksheet is valid, indicated by the value of the Precentage of Agreement (PA), it is known that the reliability of the results of observations from both observers / validators for the student worksheet is validity of the format aspect of $100 \%$, the language aspect is $97 \%$, and the content aspect is $100 \%$ that the developed worksheets can be used for further tests. The student worksheet is a set of questions and information that can be used to help students understand complex ideas because they have been arranged systematically. The information contained in the worksheets is in the form of contextual problems around students. According to Munifah (2019) Student Worksheets have a role important in evaluating the topics that have been taught by giving assignments relevant, to maximize students abilities with learning resources.

In the Student Book, it is known that the validity of the format aspect is $87 \%$, the language aspect is $100 \%$, and the side aspect is $100 \%$, so that all aspects of the Student Book are valid. Student books can be said that one source of learning. The student book explains all about flood disasters and flood disaster mitigation with the aim that students can understand about flood disasters and what actions can be taken before, during and after a flood disaster. Student books are books that are intended as a guide to facilitate student learning activities to master certain materials, besides, they are also used to carry out learning process activities that contain activity sheets with the aim that they can be held (Sahi, 2014). From this statement the student book on flood disaster mitigation that has been made has fulfilled the learning activities to be achieved, so that the student book is valid for direct trials at school.

The test questions developed were valid, with the value of the content aspect validity of $97 \%$ and the language aspect of $93 \%$. From these results, the test questions that have been made can be used for further trials and can be used as a basis for knowing students' initial knowledge of the flood material if the test questions are given at the beginning of learning (pretest). In addition, the developed test questions were also given at the end of the lesson with the aim of knowing the progress and development and success of students after experiencing or carrying out learning activities with the role-playing-based OrSAEv model for a period of 2 weeks. This is in accordance with Pradilasari et al., (2019) the purpose of giving test questions is to see the level of student understanding of the material delivered and to determine the completeness of student learning outcomes.

Furthermore, the mitigation preparedness questionnaire was valid by looking at the PA value of $100 \%$. The data from the questionnaire observations were analyzed by calculating the frequency of each point contained in the questionnaire. The development of the mitigation questionnaire is in written form because students put their thoughts in writing, with a combined type of questionnaire, where some of the questions in the questionnaire are provided with answers and some are in the form of essays. The answers to the questions contained in the questionnaire represent the objectives to be achieved in the role-playing-based learning of the OrSAEv model, 
Development of OrSAEv Model Learning Materials Based on Role-Playing of Against Flood Disaster Mitigation Preparedness, Anxiety and Enjoyment of Junior High School

according to Setiani (2016) the questionnaire is used to describe the answers of students about questions in the form of factual data relating to students.

In addition to the above questionnaire, the Enjoyment questionnaire was also given, the validity of all aspects of the Student enjoyment questionnaire was valid by looking at the PA value of $100 \%$. The questions in the questionnaire represent feelings of enjoyment and discomfort that students want to know when they simulate flood disasters, and can be used to answer the learning objectives of the role-playing-based OrSAEv model. According to Hyndman et al., (2013) enjoyment questionnaire instruments used to assess the suitability of school play areas with children's physical activities through the environment so that children's enjoyment can be found in the school context.

The last one is the anxiety questionnaire, the validity of all aspects of the student anxiety questionnaire is valid by looking at the PA value of $100 \%$. The answer to this questionnaire is considered to be able to present the feelings of students that occur before doing the simulation and after the simulation. A higher anxiety rating uniquely predicts lower objective performance and a lower attitude or ability rating on the measure assigned to each of the subdomains (Huizink, 2016).

Table 2. The results of the recapitulation of observations of learning feasibility.

\begin{tabular}{cc}
\hline Implementation & IJA Value \\
\hline Lesson Plans Meeting 1 & 94.1 \\
Lesson Plans Meeting 2 & 93.8 \\
Lesson Plans Meeting 3 & 92.9 \\
\hline
\end{tabular}

Assessment of the practicality of learning devices is measured based on the results of the implementation of the lesson plans and student responses to field trials. The average value of the implementation of the lesson plans in the preliminary, core and closing activities at the 1st meeting was $94.1 \%$, the 2 nd meeting was $93.8 \%$ and the 3 rd meeting was $92.9 \%$, all of which were categorized as very good with an average score $\geq 75$. These results indicate that learning has taken place according to the plan set out in the lesson plan. It is said to be carried out well in learning because the components that are in the lesson plan, such as learning objectives, material, methods, learning steps, time allocation etc. are carried out by the teacher according to what has been developed. Meanwhile, the results of the student response data analysis showed that students gave good responses as indicated by the criteria of 2.5 to the learning activities and learning tools provided by the teacher. This data is in accordance with Utaminingsiih et al., (2018) lesson plan which can accommodate learning difficulties experienced by students and arranged according to class conditions and student needs in the learning process.

Table 3. The results of the student poster skills analysis.

\begin{tabular}{|c|c|c|c|c|}
\hline Numb. & Rated aspect & Criteria & Score & Total \\
\hline \multicolumn{5}{|c|}{ Group 1} \\
\hline 1 & Title & $\begin{array}{l}\text { The title of the poster is catchy but not } \\
\text { curious }\end{array}$ & 2 & \multirow{4}{*}{8} \\
\hline 2 & \multirow{2}{*}{$\begin{array}{l}\text { Poster image } \\
\text { Contents }\end{array}$} & The poster image is clear but not inspiring & 2 & \\
\hline 3 & & $\begin{array}{l}\text { Can describe } 2 \text { preparations that can be made } \\
\text { to deal with floods correctly }\end{array}$ & 2 & \\
\hline 4 & Writing & Posters are written systematically but do not & 2 & \\
\hline
\end{tabular}


Development of OrSAEv Model Learning Materials Based on Role-Playing of Against Flood Disaster Mitigation Preparedness, Anxiety and Enjoyment of Junior High School

\begin{tabular}{|c|c|c|c|c|}
\hline Numb. & Rated aspect & Criteria & Score & Total \\
\hline & & use the correct rules & & \\
\hline \multicolumn{5}{|l|}{ Group 2} \\
\hline 1 & Title & $\begin{array}{l}\text { The title of the poster is catchy but not } \\
\text { curious }\end{array}$ & 2 & \multirow{4}{*}{7} \\
\hline 2 & Poster image & The poster image is clear but not inspiring & 2 & \\
\hline 3 & Contents & $\begin{array}{l}\text { Can describe at least } 1 \text { preparation that can } \\
\text { be done to deal with floods correctly }\end{array}$ & 1 & \\
\hline 4 & Writing & $\begin{array}{l}\text { Posters are written systematically but do not } \\
\text { use the correct rules }\end{array}$ & 2 & \\
\hline \multicolumn{5}{|l|}{ Group 3} \\
\hline 1 & Title & $\begin{array}{l}\text { The title of the poster is catchy but not } \\
\text { curious }\end{array}$ & 3 & \multirow{4}{*}{9} \\
\hline 2 & Poster image & The poster image is clear but not inspiring & 3 & \\
\hline 3 & Contents & $\begin{array}{l}\text { Can describe at least } 1 \text { preparation that can } \\
\text { be done to deal with floods correctly }\end{array}$ & 1 & \\
\hline 4 & Writing & $\begin{array}{l}\text { Posters are written systematically but do not } \\
\text { use the correct rules }\end{array}$ & 2 & \\
\hline
\end{tabular}

Table 4. The results of student skills recapitution in the form of a flood mitigation simulation video.

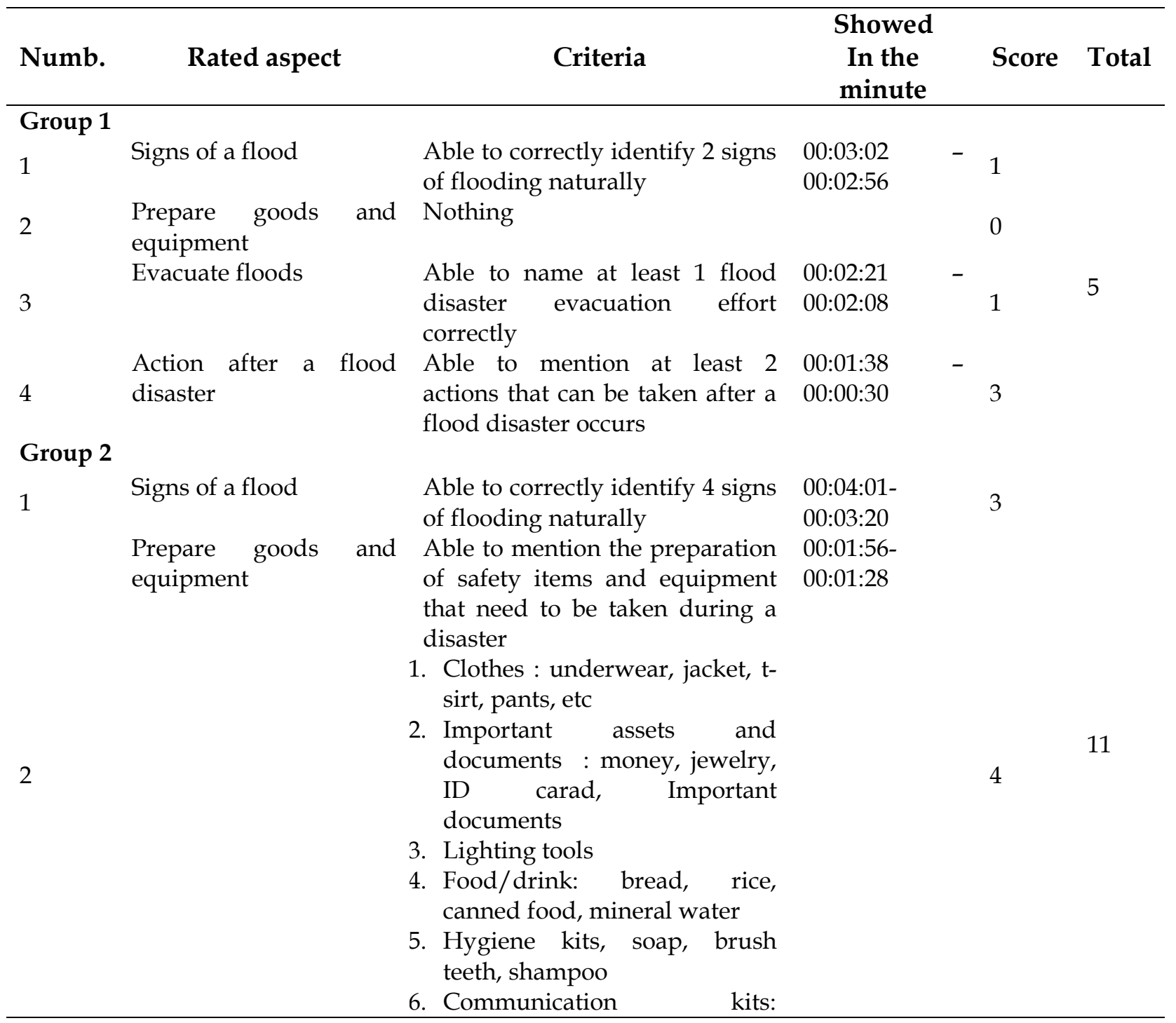


Development of OrSAEv Model Learning Materials Based on Role-Playing of Against Flood Disaster Mitigation Preparedness, Anxiety and Enjoyment of Junior High School

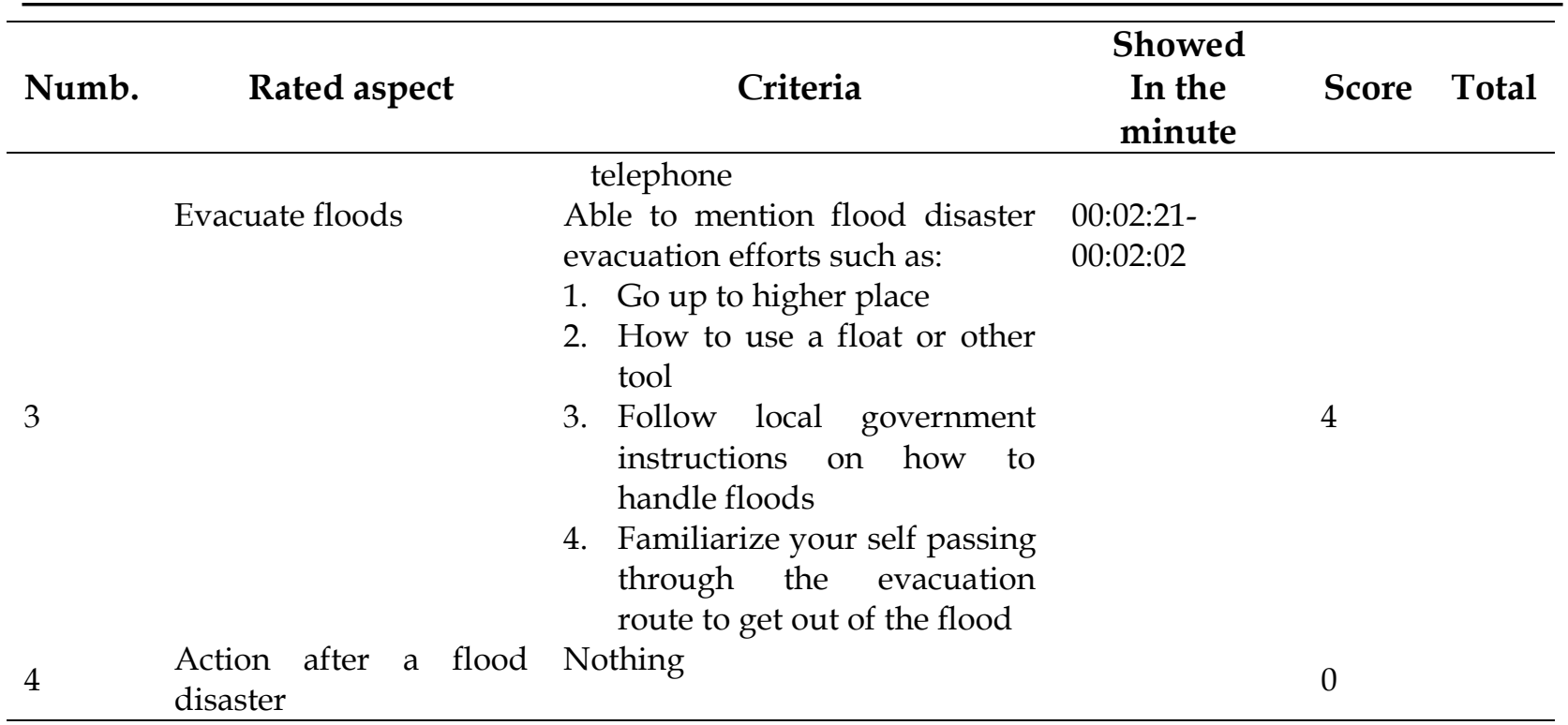

Assessment of the effectiveness of learning devices is measured based on the product's cognitive learning outcomes, students' psychomotor learning during the field testing process. Before carrying out the learning process, first an initial measurement is carried out in the form of a pretest. The pretest results were analyzed to determine the normal and homogeneous samples used. The homogeneity test was carried out using SPSS and the results were 0.442 which had a significant value $>0.05$ and the data was homogeneous. The normality test was carried out with SPSS in class A (control class) and the value was 0.094 and class B (experimental class) was 0.097, because the significance value was $>0.005$, the data were normal. The two tests are required so that the next test, the Paired T-Test, can be done. The significance value of both classes is $0.00<0.05$, from these results it can be concluded that there is a significant difference between the pretest and posttest scores of the two classes, namely class A and class B. of 0.004 , the significance value is $<0.005$ which states there is a difference between the class given the treatment and the control class. Based on this, it is known that the use of roleplaying-based learning tools with the OrSAEv model can help students achieve completeness of learning outcomes (individual and classical). This is because the learning tools developed provide information to students in detail about the material being taught, and encourage students to be more active in finding sources related to the material conveyed. According to Bloom (1976) complete learning is a learning approach that is focused on students' mastery of something being learned.

Psychomotor learning outcomes in the form of poster results are categorized as quite good criteria. Based on the calculation of the poster analysis group 1 gets a score of 2, it is included in the enough category. For group 2 the score was 1.8 in the sufficient category. Furthermore, group 3 got a score of 2.3 in the good category. Based on the description, the first hypothesis can be answered, namely the OrSAEv model learning device is effective for use in teaching and learning activities. In developing these tools, it shows that students have obtained broader information to make them able to work in the form of writing. According to Water (2015) it shows that students who write posters well know extensive information and good writing skills. However, there are several aspects that are in the indicators made by the teacher that are not included in the posters written by the students. 
Development of OrSAEv Model Learning Materials Based on Role-Playing of Against Flood Disaster Mitigation Preparedness, Anxiety and Enjoyment of Junior High School

Based on the explanation of the results of the analysis of psychomotor abilities in the form of a flood disaster mitigation simulation video, it can be used to answer the second hypothesis, namely that students who are given Role-playing-based OrSAEv learning have more influence on flood disaster mitigation preparedness than students who are given learning as usual. Both groups appear to have been able to mention several aspects as a form of flood disaster mitigation. The scores obtained by the two groups, respectively were 1.3 in the sufficient category for group 1 and 2.8 in the best category for group 2. According to Famulasih (2020) research shows that with drama performances, students can improve pronunciation, fluency, accuracy, mastery of voice, and body language to increase their confidence in communication. The difference in the scores of the two groups was very far, it could be influenced by several factors, one of which was the readiness of group members in making scenarios, readiness what is meant is the collection of information related to the theme determined by each group. The OrSAEv model materials based playing-based is said to achieve the desired psychomotor abilities seen from the ability of students to play a role to simulate actions before a disaster, during a disaster, and after a flood. Learning outcomes achieved in developing the OrSAEv model (Madlazim et al., 2020). Disaster preparedness: disaster response attitudes and post-disaster evacuation skills.

\section{The results of student enjoyment while doing the simulation}

Assessment of student enjoyment when simulating in a negative direction is 1.9 and a positive enjoyment of 1.8 is categorized as sufficient, with very little difference between positive and negative enjoyment, namely 0.1 . From these data, it shows that enjoyment tends to be lower. This can answer the hypothesis formulation, namely students who are given OrSAEv learning model based role-playing has more influence on enjoyment, but in a negative direction in the sense that students are not too happy in taking action by playing roles. This is contrary (Piaget, 1951) to saying that activities such as playing used in learning can encourage students to participate and develop work skills in groups, it makes students enjoy more comfortable learning. According to Subandi et al., (2019) role playing is an effective approach to improving skills, social skills, and negotiation skills. Students are more positive about school and subjects that are considered difficult.

The things that can cause students to feel uncomfortable in the role-playing-based learning process of the OrSAEv model are: (1) Limited time for students. One of the effects of the ineffectiveness of online learning is the reduction of lesson hours due to limited internet quota and the difficulty of the internet network. However, time is considered very important as an arrangement for role-playing activities, with sufficient time available to ensure that students are involved and interpret their roles, limited time when giving reflection at the end of each lesson. (2) Limited access to resources (students). Although teaching aids should not be the focus of role playing activities, access to certain resources (access to computers, mobile phones and the internet) may be deemed necessary for students to fully reach their potential for involvement in these role-playing activities. (3) Lack of social skills (group) or reluctance to participate. Certain students may not be willing to participate or may not demonstrate skills that may be required for the performance of role playing activities. In role playing it is necessary to have certain boundaries / regulations with role guidelines provided and 
Development of OrSAEv Model Learning Materials Based on Role-Playing of Against Flood Disaster Mitigation Preparedness, Anxiety and Enjoyment of Junior High School

activities to be organized in a safe, comfortable, and an unhurried learning environment. Students who refuse to participate should be able to function as observers and share their thoughts and perspectives at the end of the simulation.

\section{The results of student anxiety when doing the simulation}

Assessment of student anxiety when simulating in the negative direction of 2.5 and positive anxiety of 2.7 the value is categorized as well, with very little difference between positive and negative anxiety, namely 0.2 . From these data shows a tendency to lower anxiety or only a few students who feel anxious before doing the simulation. This can answer the hypothesis formulation, namely that students who are given OrSAEv learning model based role-playing has more influence on anxiety.

There is a negative relationship between enjoyment and anxiety, in this study where one of the variables obtained a positive value and on the other hand, there is a negative variable value which is likened to a seesaw. The enjoyment variable has a negative value because anxiety is positive (students are not anxious). Students with low anxiety usually use more flexible communication strategies such as speaking spontaneously rather than memorizing and are less burdensome from a task they are doing. In addition (Baudreau et al., 2018), the level of anxiety is closely related to the emotions of a person, student behavior will change when the level of anxiety increases (Reeve, 2015). Emotions seem to work independently of one another. Determine the two emotions interact, converge or diverge during certain events. This can affect the difference between feelings or emotions of enjoyment and anxiety. The relationship between anxiety and enjoyment can be reexamined with improvements in different activities during learning, classroom environments that may be more natural and comfortable, use of different software.

\section{CONCLUSIONS}

Based on the results of the research data analysis, it can be concluded that the OrSAEv model based role-playing learning materials for the is appropriate for learning and is effective in improving flood disaster mitigation preparedness by simulations. From the simulation results, it can also be seen that students' emotions in the form of anxiety and enjoyment. Students feel unenjoy in simulating but students do not experience significant anxiety, this incident can be caused by various factors. The research was conducted during the Covid-19 pandemic, schools implemented online learning, as an implication of the research that has been done, recommendations for further research are obtained is teachers need to provide pre-learning activities with the aim of introducing students to disaster mitigation activities, so that students can adapt well to a new learning atmosphere where learning activities emphasize the role of students. Ensure the students understand the use of media or software to be used for teaching and learning activities, so that students actively participate in learning. Better classroom introduction and management are needed in implementing the OrSAEv learning model based role-playing so that learning activities are carried out according to what is desired.

\section{REFERENCES}

Atmojo, S. E., Rusilowati, A., Dwiningrum, S. A., \& Skotnica, M. (2018). The reconstruction of disaster knowledge through thematic learning of science, environment, technology, and 
Development of OrSAEv Model Learning Materials Based on Role-Playing of Against Flood Disaster Mitigation Preparedness, Anxiety and Enjoyment of Junior High School

society integrated with local wisdom. Jurnal Pendidikan IPA Indonesia, 7(2), 204-212.

DOI: 10.15294/jpii.v7i2.14273

Baudreau, C., Macltyre, P. D., \& Dewaele, J.-M. (2018). Enjoyment and anxiety in secon language communication: an idodynamics approach. Studies in Second Language Learning and Teaching, 8(1), 149-170. doi: 10.14746/ssllt.2018.8.1.7

Bloom, B. (1976). Human characteristics and social learning. New York: McGraw-Hill.

Brom, C., Dobrovolný, V., Děchtěrenko, F., Stárková, T., \& Bromováa, E. (2019). It's better to enjoy learning than playing: motivational effects of an educational live action roleplaying game. Frontline Learning Research, 7(3), 64-90. DOI: 10.14786/flr.v7i3.459

Cobbett, S., \& Snelgrove-Clarke, E. (2016). Virtual verses face-to-face clinical simulation in relation to student knoweldge, anxiety, and self-confidence in maternal newborn nursing: a randomized controlled trial. Nurse Education Today, 45, 179-184 doi: 10.1016/j.nedt.2016.08.004

Desfandi, M. (2014). Urgensi kurikulum pendidikan kebencanaan berbasis kearifan lokal di indonesia. sosio didaktika. 1(2), 191-198. DOI: $10.15408 /$ sd.v1i2.1261

Dikmenli, Y., Yakar, H., \& Konca, A. S. (2018). Development of disaster awareness scale: a validity and reliability study. International Geographical Education Online, 8(2), 206-220. http://www.rigeo.org/vol8no2/Number2Summer/RIGEO-V8-N2-2.pdf

Dohaney, J., Erik, B., Kennedy, B., Wilson, T. M., \& Lindsay, J. M. (2015). Training in crisis communication and volcanic eruption forecasting: design and evaluation of an authentic role-play simulation. Journal of Applied Volcanology, 1-26. DOI: 10.1007/11157_2016_50

Elfiana, D. E., Madlazim, Hariyono, E., \& Munasir. (2019). Development of The OrSAEv learning materials:preliminary study of student's knowledge about earthquake and tsunami mitigation. Journal of Physics Conference Series. Surabaya: IOP Publishing. DOI: $10.1088 / 1742-6596 / 1417 / 1 / 012083$

Famularsih, S., (2020). The Implementation of classical puppet drama performance to improve english speaking skill for international class program students. International Journal of Recent Educational Education, 1(2), 116-123. DOI: https:// doi.org/10.46245/ijorer.v1i2.41

Fernandes , A., Black, J., Jones, M., Wilson, L., Salvador-Carulla, L., Astell-Burt, T., \& Black, D. (2015). Flooding and mental health: A systematic. Plos One, 10(4) 1-20. https://doi.org/10.1371/journal.pone.0119929

Fitzgerald, A., Huang, S., Sposato, K., Wang, D., Claypool, M., \& Agu, E. (n.d.). The exergame enjoyment questionnaire (EEQ): An instrument for measuring exergame enjoyment. Computer Science Dept., Worcester Polytechnic Institute, Worcester, 3397-3406. DOI: $10.24251 /$ HICSS.2020.416

Hales, T., \& Cashman, K. V. (2018). Simulating social and political influences on hazard analysis through a classroom role playing exercise. Journal of Geoscience Education, 56(1), 54-60. https://doi.org/10.5408/1089-9995-56.1.54

Hydman, B., Telford, A., Finch, C., Ullah, S., Benson, A. C. (2013). The development of the lunchtime enjoyment of activity and play questionnaire. Journal of School Health, 83(4), 257-264. https:// doi.org/10.1111/josh.12025

Huizink, A. C., Delforterie, M. J., Scheinin, M. N., Tolvanen. M., Karlsson. L., Karlsson. H. (2016). Adaption of pregnancy anxiety questionnaire-revised for all pregnant women regardless of parity: PRAQ-R2. Arch Womens Ment Health, 19, 125-132. DOI 10.1007/s00737-015-0531-2

Indriasari, F., N. (2016). Pengaruh pemberian metode simulasi mitigasi siaga gempa bumi terhadap kesiapsiagaan anak di Yogyakarta. The Soedirman Journal of Nursing, 11(3), 1-7. DOI: http://dx.doi.org/10.20884/1.jks.2016.11.3.700

Isna, B. U., Madlazim, Hariyono, E., \& Suprapto, N. (2019). Development of OrSAEv model learning materials to strengthen the characters of tsunami disaster mitigation for middle school 
Development of OrSAEv Model Learning Materials Based on Role-Playing of Against Flood Disaster Mitigation Preparedness, Anxiety and Enjoyment of Junior High School

students (Preliminary Study). MISEIC. Surabaya: IOP Publishing. DOI: 10.1088/1742$\underline{6596 / 1417 / 1 / 012082}$

Jose, M. M., \& Dufrene, C. (2014). Educational competencies and technologies for disaster preparedness in undergraduate nursing education: An integrative review. Nurse Education, 34(4), 543-551. DOI: 10.1016/j.nedt.2013.07.021

Kastolani, W., \& Mainaki, R. (2018). Does educational disaster mitigation need to be introduced in school? SHS Web of Conferences . DOI: 10.1051/shsconf/20184200063

Madlazim, Rahmadiarti, F., Masriyah, Indana , S., Sunarti , T., \& Prahani, B. K. (2019). Buku model pembelajaran ORSAEV untuk meningkatkan kesiapsiagaan bencana bagi mahasiswa calon guru . Surabaya: JDS.

Madlazim, Rahmadiarti, F., Masriyah, Indana, S., Sunarti, T., \& Prahani, B. K. (2020). An OrSAEv learning model to improve the disaster preparedness of STEM teacher candidates. WTEE, 18(2), 231.

Marskole, P., Mishra, A., Kumar, P., Gaur, P., Aharwar, P., Patidar, P., \& Shejwar, P. (2018). A study to assess awareness on disaster management among school going children in Gwalior (M.P.). International Journal of Community Medicine and Public Health. 5(4), 1371-1375. DOI:10.18203/2394-6040.IJCMPH20180949

Munifah, Tsani, I., Yasin, M., Zuroidah, N., Huda, S., Lestari, F., Rahmat, A. (2019). Management development of student worksheets to improve teacher communication skills: A case study on self-efficacy and student achievement. Journal for the Education of Gifted Young, 7(4), 777-798. https:// doi.org/10.17478/jegys.625618

Nesari, A.J., \& Heidari M. (2014). The important role of lesson plan on educational achievement of Iranian EFL teachers attitudes. International Journal of Foreign Language Teaching $\mathcal{E}$ Research, 3(5), 25-31. Corpus ID: 148099164

Nielsen, B., \& Harder, N. (2013). Causes of Student Anxiety during Simulation:What the Literature Says. Clinical Simulation Nurse, 9(11), 507-512. DOI:https://doi.org/10.1016/j.ecns.2013.03.003

Permendikbud. 2016. Standar proses pendidikan dasar dan menengah. Jakarta : Permendikbud Piaget J. (1951). Play, dreams, and imitation. New York : [s.n.].

Rradilasari, L., Gani, A., Khaldun, I. (2019). Pengembangan media pembelajaran berbasis audio visual pada materi koloid untuk meningkatkan motivasi dan hasil belajar siswa SMA. Indonesian Journal of Science Education, 7(1), 9-15. DOI: 10.24815/jpsi.v7i1.13293

Puruhita, I. R. (2020). Pembelajaran role playing berbasis video dan lagu pada materi mitigasi dan adaptasi bencana alam. Jurnal Profesi Keguruan, 6(1), 64-72.

Rahayu, S., Madlazim, Prastowo, T., \& Hariyono, E. (2019). Development of OrSAEv model learning materials to improve tsunami disaster mitigation skills (Preliminary Study). Advances in Computer Science Research, 218-221. https://doi.org/10.2991/miseic19.2019 .51

Reeve J. (2015). Understansing motivation and emotion (5th edition). Hoboken : Wiley and Sons.

Sahi, R. (2014). Memahami Buku Guru Dan Buku Siswa.

Sari, S. A., Dirhamsyah, M., \& Finzia, P. Z. (2014). The influence of earthquake disaster risk reducation simulation towards the preparedness knowledge for elementary school student of Ulee Paya, Pulo Breuh, Aceh Besar, Indonesia. International Journal of Education and Research, 2(9), 420-426. DOI: 10.11591/edulearn.v9i3.2301

Setiani, F. (2016). Pengaruh proses pembelajaran terhadap soft skill siswa bidang kompetensi. Bandung: repository.upi.edu.

Siregar, N. (2020, 911). Belajar dan Pembelajaran. Retrieved from http://akademik.uhn.ac.id/

Subandi, Hasana, I. F., Dewi, L. L., Jannah, S. R. (2019). Implementation of group counseling and roleplaying: the investigation of students social interaction improvement. Islamic Guidance and Counseling Journal, 3(1), 32-37. https://doi.org/10.25217/igcj.v3i1.613 
Development of OrSAEv Model Learning Materials Based on Role-Playing of Against Flood Disaster Mitigation Preparedness, Anxiety and Enjoyment of Junior High School

Suharli. (2015). Teori belajar dan model penerapannya dalam pembelajaran. (Suharli, Performer) Bandung, Jawa Timur.

Syuaib, Z., M. (2013). Pengaruh strategi pembelajaran simulasi vs bermain peran dan sikap siswa terhadap pengetahuan dan kesiapsiagaan tentang bencana alam. Jurnal Pendidikan Humaniora, 1(2), 177-189. oai:doaj.org/article:9b689cf384ce4f5da4f53a82cedefdf7

TIM Redaksi, P. (2013). Pemerintah kabupaten bojonegoro.

Tkachuck, M. A., Schulenberg , S. E., \& Lair, E. C. (2016). Natural disaster preparedness in college students: implications for institutions of higher learning. Thesis : University of Mississippi.

Utaminingsih, R., Rahayu, A., Andini, D. W. (2018). Pengembangan RPP IPA sekolah dasar berbasis problem-based learning untuk siswa learning disabilities. Jurnal Inovasi Pendidikan IPA, 4(2), 191-202. DOI: https:/ / doi.org/10.21831/jipi.v4i2.21401

Walcott, P., \& Corbin-Babb, N. (2016). Improving caribbean undergraduates' enjoyment, engagement and learning using a 3D role playing game. Caribbean Educational Research Journal, 4(1), 127-143.

Wang, C., Hou, J., Miller, D., Brown, I., \& Jiang, Y. (2019). Flood risk management in sponge cities: The role of integrated simulation and 3D visualization. International Journal of Disaster Risk Reduction, 39, 1-11. https://doi.org/10.3390/w12102788

Water, N. (2015). A Poster Assignment Connects Information Litericy and Writing Skills. 10(1).

Winarmi, E. W., \& Purwandari, E. P. (2018). Disaster risk reduction for earthquake using mobile learning application to improve the students understanding in elementary school. Mediterranean Journal of Social Sciences, 9(2), 205-214. DOI: 10.2478/mjss-2018-0040

Wirth, W., Ryffel, F., Pape, T. V., \& Karnowski, V. (2013). the development of video game enjoyment in a role playing game. Cyberpsychology, Behavior, And Social Networking, 16(4), 260-264. doi: 10.1089/cyber.2012.0159

\footnotetext{
*Novia W. Kusumaningrum (Corresponding Author)

Postgraduate,

Universitas Negeri Surabaya,

Jl. Lidah Wetan, Surabaya, East Java, 60213, Indonesia

Email: noviawidiantik@gmail.com

Prof. Dr. Madlazim

Postgraduate,

Universitas Negeri Surabaya,

Jl. Lidah Wetan, Surabaya, East Java, 60213, Indonesia

Email: madlazim@unesa.ac.id

Dr. Tarzan Purnomo

Postgraduate,

Universitas Negeri Surabaya,

Jl. Lidah Wetan, Surabaya, East Java, 60213, Indonesia

Email: tarzanpurnomo@unesa.ac.id
} 